\title{
Phytochemical Analysis and Antibacterial Activity of Purple Leaf Extract [Graptophyllum pictum (L.) Griff] Against Streptococcus mutans
}

\author{
Devi Eka Juniarti, DDS, MDSc, ${ }^{1}$ Tuti Kusumaningsih, DDS, MDSc, PhD, ${ }^{2}$ Wisnu Setyari Juliastuti, DDS, MDSc, ${ }^{2}$ \\ Adioro Soetojo, DDS, MDSc, $\mathrm{PhD}^{1}$ and Nabilla Dara Wungsu, BDS ${ }^{1}$ \\ ${ }^{1}$ Department of Conservative Dentistry, Faculty of Dental Medicine, Universitas Airlangga, Surabaya, Indonesia \\ ${ }^{2}$ Department of Oral Biology, Faculty of Dental Medicine, Universitas Airlangga, Surabaya, Indonesia
}

\begin{abstract}
Background. Streptococcus mutans is the leading cause of dental caries. One of many medicinal plants, purple leaf [Graptophyllum pictum (L.) Griff], which contains flavonoids, alkaloids, tannins, steroids, and saponins, is a potential antibacterial agent.

Objective. This study aimed to determine the antibacterial activity of purple leaf extract (Graptophyllum pictum L. Griff) against Streptococcus mutans.

Methods. Streptococcus mutans were suspended in several Graptophyllum pictum (L.) Griff extract concentrations in a BHIB medium using the dilution method so that the concentration of $100 \%, 50 \%, 25 \%, 12.5 \%, 6.25 \%, 3.12 \%$, $1.56 \%, 0.78 \%$ were obtained. Each tube was incubated for 24 hours, then subcultured in a Tryptone Yeast Extract Cystine medium in a petri dish using a spreader. Each petri dish was set for 24 hours; the growth of the colony, using CFU/mL unit, was manually calculated. The samples were then subjected to microbiological analysis. The Tukey's Honest Significant Difference test was performed to determine if the relationship between the sets of data in the treatment group is statistically significant $(p<0.05)$.

Results. Purple leaf extract contains bioactive compounds such as flavonoid, alkaloid, tannin, triterpenoid/ steroid, and saponin. The Minimum Inhibitory Concentration (MIC) of Graptophyllum pictum (L.) Griff against Streptococcus mutans was in concentration 3.125\%, and the Minimum Bactericidal Concentration (MBC) was in concentration $6.25 \%$.
\end{abstract}

Conclusion. Purple Leaf Extract [Graptophyllum pictum (L.) Griff] has antibacterial activity against Streptococcus mutans.

Key Words: antibacterial, medicine, phytochemical, Streptococcus mutans

\section{INTRODUCTION}

Paper presented in the Temu IImiah Nasional-Internasional ke-8 (TIMNASS 8) on February 27-29, 2020 at the Shangri-La Hotel Surabaya, Indonesia.

Corresponding author: Devi Eka Juniarti, DDS, MDSc. Department of Conservative Dentistry

Faculty of Dental Medicine

Universitas Airlangga

Surabaya, Indonesia

Email: devi-e-j@fkg.unair.ac.id / devi.fkgunair@gmail.com
Based on the Basic Health Research results in 2018, the prevalence of pulpitis in Indonesia is relatively high. The number of patients with pulpitis is approximately 160,000 within one year. ${ }^{1}$ One of the leading causes of pulpitis is dental caries. The microorganism that starts the caries process is Streptococcus mutans. ${ }^{2}$

Public health education on dental hygiene (toothbrushing, dental floss use, and mouthwash) was carried out. Mouthwash helps reduce microbial plaques. ${ }^{3,4}$ In some cases, the use of an antiseptic mouthwash for an extended period can cause bacterial resistance. ${ }^{5}$ Previous studies reported an increased resistance of Streptococcus mutans to fluoride 
when used over a long period. Therefore, the need for an alternative oral antiseptic. ${ }^{6}$

Research has been done to investigate natural ingredients as an antibacterial agent. Purple leaf [Graptophyllum pictum (L.) Griff] is one of traditional medicinal plants with known antibacterial properties. ${ }^{7}$ It is expected that the use of these plants as herbal medicine can reduce the number of Streptococcus mutans, a tpathogenic bacterium that causes dental caries. The known chemical constituents of purple leaves include flavonoids, tannins, non-toxic alkaloids, steroids, saponins, and glycosides. ${ }^{8}$ Some of these active compounds work synergistically against the antibacterial potential of purple leaves. ${ }^{9}$ This study, therefore, aimed to determine the antibacterial activity of purple leaf extract [Graptophyllum pictum (L.) Griff] against Streptococcus mutans.

\section{MATERIALS AND METHODS}

\section{Experimental Design}

This research is an experimental laboratory study. The preparation, manufacture, and phytochemical analysis of purple leaf extract were carried out at the Assessment Service Unit, Faculty of Pharmacy, Airlangga University, Surabaya, Indonesia. The microbiological tests were carried out at the Microbiology Laboratory Research Center, Faculty of Dentistry, Airlangga University, Surabaya, Indonesia.

The ethical clearance committee approved this research of the Faculty of Dental Medicine, Airlangga University, Indonesia (No.248 / HRECC.FODM / IX / 2018). The subject was Streptococcus mutans ATCC 25175.

\section{Simplicia Powder Preparation}

The purple leaves [Graptophyllum pictum (L.) Griff.] of the luridosanguineum (Sims) variety, were taken from the Botanical Gardens of Purwodadi, Pasuruan, Indonesia, and identified at the Indonesian Institute of Plant Conservation (IIPC). The purple leaves were washed with water until clean, cut into pieces, drained, dried, and blended to powder. ${ }^{10}$

\section{Extraction Process}

The simplicia powder was macerated with $96 \%$ ethanol, left at room temperature $\left(28^{\circ} \mathrm{C}-32^{\circ} \mathrm{C}\right)$ for two days, protected from light, and often stirred, then separated. The pulp was re-macerated with a $96 \%$ ethanol solvent. This was carried out until a clear liquid was obtained. All the macerates were combined into one and evaporated using a rotary evaporator until a thick ethanol extract was obtained. The extract was freeze-dried at $-40^{\circ} \mathrm{C} .{ }^{11}$

\section{Phytochemical Screening}

Phytochemical screening of the purple leaf extract by TLC-Densitometry method was made using silica gel F254 pre-coated plates, mobile phase $n$-bexane:ethyl acetate (7:3), Toluol:ethyl acetate (7:3), chloroform-methanol (4:6, 5:5), and chloroform:ethyl acetate (8:2). The Lieberman-
Burchat stain was used to detect the presence of terpenoid/ steroid compounds. The $\mathrm{FeCl}_{3}$ test was used to determine the presence of flavonoid and tannin compounds.

A $10 \mu \mathrm{L}$ ethanol extract was bottled and placed in a TLC plate. The chromatographic vessel was saturated with a developing solution, then eluted to the development limit. The plate was removed, dried, and then observed under UV light. It was then sprayed with a stain viewer and heated for 10 minutes in an oven at $110^{\circ} \mathrm{C}$. The resulting color was noted, and the $\mathrm{Rf}$ value calculated. ${ }^{12}$

\section{Microbiological Tests}

Streptococcus mutans culture was suspended in a Brainheart Infosion Broth (BHIB) media until the turbidity was equivalent to the $0.5 \mathrm{Mc}$ Farland (1.5x $108 \mathrm{CFU} / \mathrm{mL}$ ) standard. The formulation of purple leaf extract was carried out by the dilution method to obtain purple leaf extracts in concentrations of $100 \%, 50 \%, 25 \%, 12.5 \%, 6.25 \%, 3.12 \%$, $1.56 \%$ and $0.78 \%$.

Twelve tubes were used, containing $0.05 \mathrm{~mL}$ of ATCC 25175 suspension, standardized with $0.5 \mathrm{Mc}$ Farland, containing the BHIB media and the purple leaf extract in various concentrations $(100 \%, 50 \%, 25 \%, 12.5 \%, 6.25 \%$, $3,12 \%, 1.56 \%, 0.78 \%)$ to determine the Minimun Inhibitory Concentracion (MIC) and the Minimum Bactericidal Concentration (MBC) of the purple leaves ethanol extract against Streptococcus mutans.

The positive control test tube $(\mathrm{K}+)$ was filled with 0.05 $\mathrm{mL}$ of Streptococcus mutans suspension and BHIB media without purple leaf extract. In contrast, the negative control test tube (K-) contained BHIB media without the addition of Streptococcus mutans and purple leaf extract to ensure there was no bacterial contamination of the media. Each group consisted of 6 samples; then, the test tubes were incubated in an anaerobic incubator at $37^{\circ} \mathrm{C}$ for 24 hours. Because dark extracts and turbidity occurred in all tubes, each tube was taken $0.1 \mathrm{ml}$, then etched on Tryptone Yeast Cystine media, and incubated anaerobically at $37^{\circ} \mathrm{C}$ for 24 hours. The presence or absence of bacterial growth was observed. The result of the bacterial growth limit streak was used as MIC conjectured. Take $0.1 \mathrm{~mL}$ of the boundary tube between bacterial growth and non-positive control, then plant it on the Tryptone Yeast Cystine media using a spreader and incubated at $37^{\circ} \mathrm{C}$ for 24 hours to cross-check the growth of Streptococcus mutans bacteria. ${ }^{5}$

The MIC was determined by counting the number of colonies that showed $90 \%$ inhibition. The MBC showed a $99.9 \%$ mortality of Streptococcus mutans on Tryptone Yeast Cystine, which was calculated manually and stated in colony-forming unit (CFU), and then was compared with the positive and negative control. The calculation was repeated three times by three different observers, and the average was taken.

The data analysis tests used in this study were the Kolmogorov-Smirnov test for normality, the non-parametric 
Kruskal-Wallis $\mathrm{H}$ test to determine if there was significant difference between the two groups, and the Tukey's Honest Significant Difference (HSD) post-hoc test to determine if the relationship between the two sets of data was significant.

\section{RESULTS}

Phytochemical analysis was first carried out for the presence of the active compounds contained in the purple leaf extract before the Streptococcus mutans antibacterial test.

Phytochemical analysis showed triterpenoid, alkaloids, glycosides, flavonoids, saponins, and tannins in purple leaves extract, as shown in Table 1.

The determination of the MIC and MBC was carried out in advance through preliminary research with serial dilution method so that the concentrations of $100 \%, 50 \%$, $25 \%, 12.5 \%, 6.25 \%, 3.12 \%, 1.56 \%$ and $0.78 \%$ were obtained (Figure 1).

Observation of purple leaves extracts [Graptophyllum pictum (L.) Griff] inhibited and eliminated the Streptococcus mutans when the colonies, expressed in CFU were counted in the Tryptone Yeast Cystine media. There was a significant decrease in the number of bacterial colonies at the 6.25\% concentration (Figures 2 and 3). This indicated that the MIC was at $3.125 \%$ concentration because the growth rate of the bacterial colony was below $10 \%$. The MBC was at the $6.25 \%$ concentration; there was no bacterial growth, as shown in Table 2 and Figure 4.

A test for normality was carried out for each group using the Kolmogorov-Smirnov test shown in Table 3 before an analysis test was carried out on Streptococcus mutans between the research groups.

The results of the normality test data using the Kolmogorov-Smirnov Test in the (+) control group showed a p-value $>0.05$ in concentrations $1.56 \%$ and $3.12 \%$. This showed that the group was normally distributed.

Tukey's HSD test result is shown in Table 5. There was a difference in the number of Streptococcus mutans, which was significant between the study treatment groups, namely positive control, concentrations of $1.56 \%$ and $3.125 \%$. The results at a concentration of $6.25 \%$ are the MBC of Graptophyllum pictum (L.) Griff's extract against Streptococcus mutans and a concentration of $3.125 \%$ is the MIC of Graptophyllum pictum (L) Griff extract against Streptococcus mutans.

Table 1. Phytochemical screening results for purple leaves extract

\begin{tabular}{ccc} 
No. & Phytochemical Test & Result \\
\hline 1 & Triterpenoid/steroid & + \\
2 & Alkaloid & + \\
3 & Flavonoid & + \\
4 & Saponin & + \\
5 & Tannin & + \\
\hline
\end{tabular}

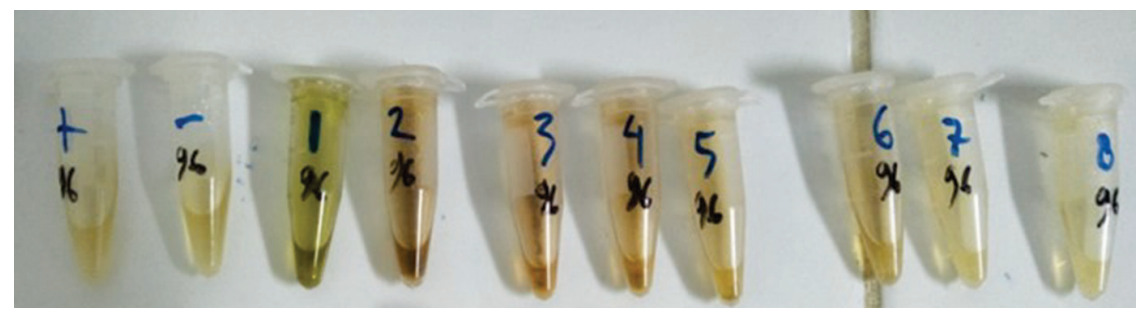

Figure 1. Serial dilution of the purple leaf [Graptophyllum pictum (L.) Griff] extract.

Table 2. Dilution test results of $96 \%$ ethanol extract of the purple leaf (Graptophyllum pictum L. Griff) with the number of Streptococcus mutans from each tube (CFU/mL)

\begin{tabular}{|c|c|c|c|c|c|c|c|c|c|}
\hline \multirow{2}{*}{ Treatment Groups } & \multicolumn{7}{|c|}{ Concentration } & \multicolumn{2}{|c|}{ Control Groups } \\
\hline & $100 \%$ & $50 \%$ & $25 \%$ & $12.5 \%$ & $6.25 \%$ & $3.125 \%$ & $1.56 \%$ & Positive & Negative \\
\hline S.mutans & - & - & - & - & - & + & + & + & - \\
\hline Average (CFU/mL) & 0 & 0 & 0 & 0 & 0 & 1.30 & 2.58 & 14.46 & 0 \\
\hline
\end{tabular}

Table 3. Results of distribution test between concentration groups with the Kolmogorov-Smirnov test

\begin{tabular}{cccc} 
Concentration & $1.56 \%$ & $3.12 \%$ & $(+)$ Control \\
Kolmogrov Sminorv Test & $\mathrm{P}=0.833$ & $\mathrm{P}=0.828$ & $\mathrm{P}=0.918$ \\
\hline
\end{tabular}

Table 5. Results of differences in the significance of effectiveness between concentration groups with the Tukey HSD Test

\begin{tabular}{ccccc}
\hline Groups & $\mathbf{N}$ & $\mathbf{3 . 1 2 5 \%}$ & $\mathbf{1 . 5 6 \%}$ & $(+)$ Control \\
\hline $3.125 \%$ & 6 & & $*$ & $*$ \\
$1.56 \%$ & 6 & $*$ & & $*$ \\
\hline
\end{tabular}

${ }^{*}$ indicated there were statistically significant differences $(p<0.05)$
Table 4. Results of the significant difference in effectiveness between the concentration groups with the Kruskal-Wallis test

\begin{tabular}{cc} 
Concentration & Sig. \\
\hline$(+)$ Control & $\mathrm{P}=0.00$ \\
$3.12 \%$ & \\
$1.56 \%$ & \\
\hline
\end{tabular}




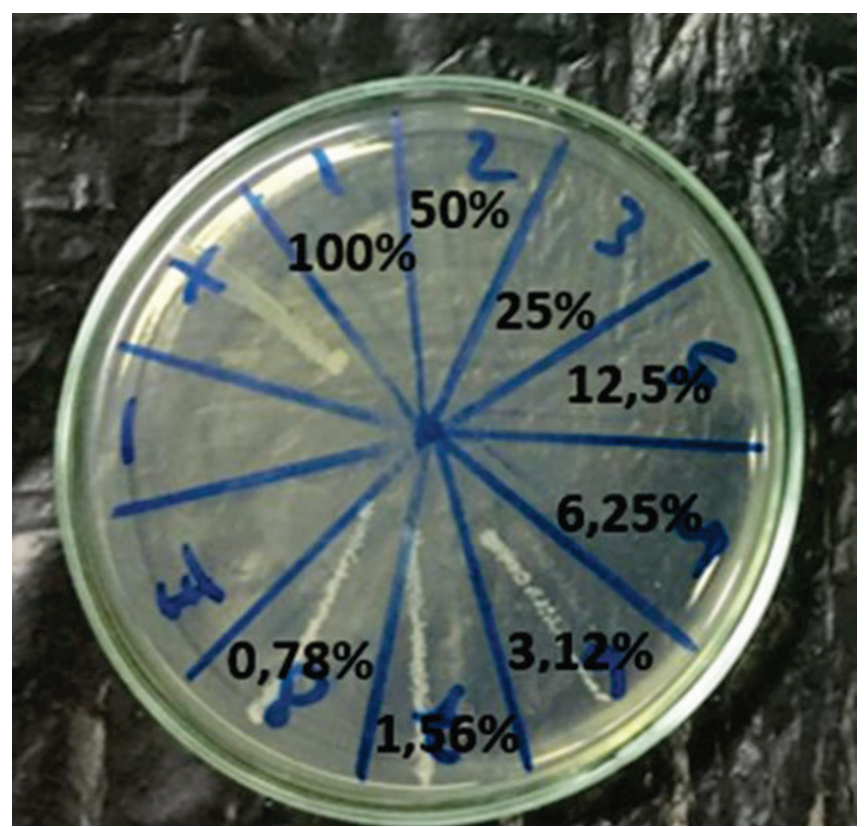

Figure 2. Results of streak on Tryptone Yeast Cystine media as a cross-check of the growth of Streptococcus mutans at concentrations of $100 \%, 50 \%, 25 \%, 12.5 \%, 6.25 \%$, $3.12 \%, 1.56 \%, 0.78 \%,(+)$ control, and (-) control.

\section{DISCUSSION}

Graptophyllum pictum has been identified as Grapthophyllum pictum (L.) Griff with letter No. 445 / IPIL06 / HM / IV / 2019. The results of identification stating that the leaves are used as a sample in this study included the caricature-plant varieties which, according to the type of Graptophyllum pictum, are often utilized for treatment. ${ }^{13}$

This study found that the purple leaf [Graptophyllum pictum (L.) Griff] has antibacterial activity against Streptococcus mutans. The MIC of the purple leaf extract for Streptococcus mutans was at $3.125 \%$, and the MBC was at $6.25 \%$. The results showed the average number of colonies growing on $(+)$ control was $14.46 \mathrm{CFU} / \mathrm{mL}$. The average number of colonies growing at a concentration of $3.125 \%$ purple leaf extract [Graptophyllum pictum (L.) Griff] was 1.30 $\mathrm{CFU} / \mathrm{mL}$, inhibiting the bacterial growth by $90.6 \%$.

At the concentration of $3.125 \%$, purple leaf extract (Graptophyllum pictum L. Griff) is considered the MIC of the Streptococcus mutans. At a concentration of $6.25 \%$, there was no growth of Streptococcus mutans, so that at a concentration of $6.25 \%$ according to the requirements of the $\mathrm{MBC}$, that can eliminate bacteria by $99.9 \%$ of the total average bacteria that managed to grow in control positive.

The use of $96 \%$ ethanol solvent for maceration of purple leaf powder is expected to have a perfect chemical content, both non-polar such as terpenoid/steroid compounds, or polar ones, namely flavonoids and tannins. Ethanol is an excellent organic solvent for extracting compounds in plants.

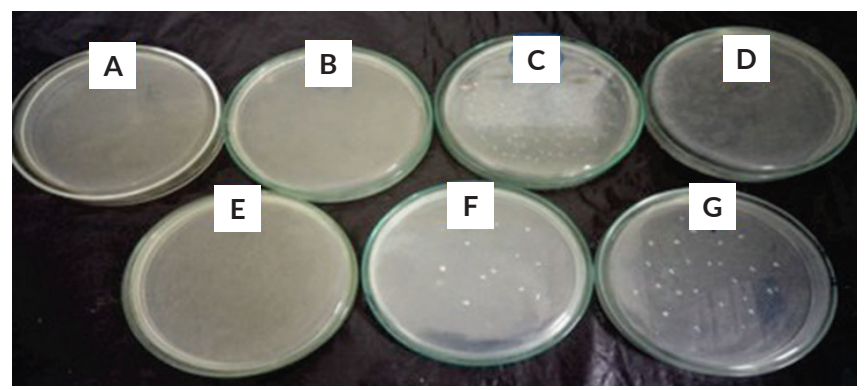

Figure 3. Cross-check the growth of Streptococcus mutans on Tryptone Yeast Cystine media using the spreader method (A) 25\%, (B) (-) control, (C) (+) control, (D) $12.5 \%$, (E) $6.25 \%$, (F) $3.125 \%$, and (G) $1.56 \%$.

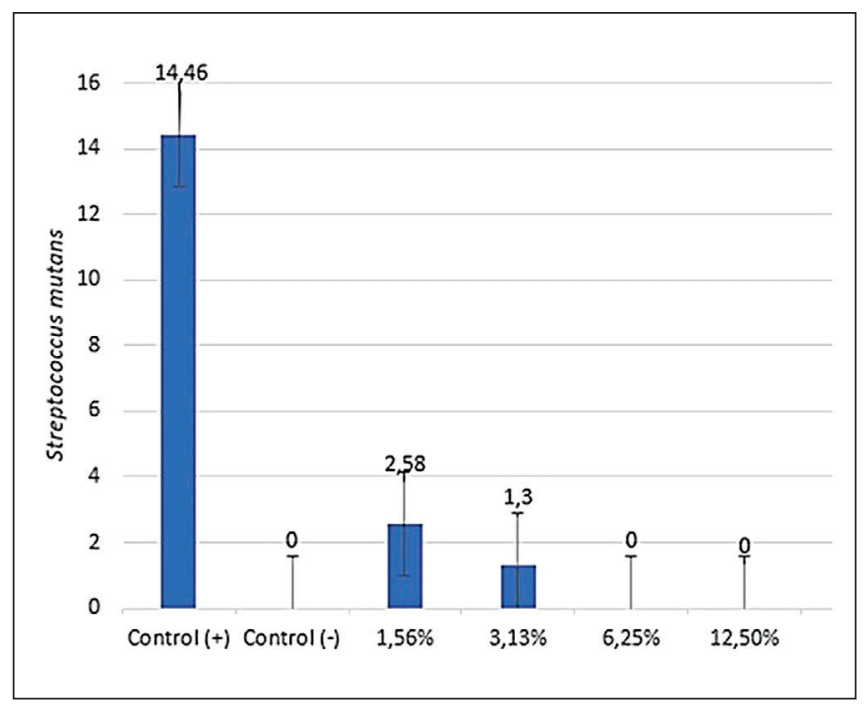

Figure 4. The average amount of Streptococcus mutans.

Therefore, it is commonly used as a solvent for various compounds because of its low polarity. ${ }^{14}$

The extract yield obtained after evaporation using a rotary evaporator is related to the components of chemical compounds extracted by ethanol solvents in this study. Polar compounds will dissolve in polar solvents, while non-polar compounds will dissolve in non-polar solvents. The size of the extract yield obtained was also influenced by the degree of powder fineness and the extraction time. The finer the powder material used and the longer the extraction time, the higher the extract yield. ${ }^{14}$

The results of the growth calculation of Streptococcus mutans in Typtone Yeast Cystine media showed that the higher the concentration of purple leaf extract (Graptophyllum pictum L. Griff), the more the bioactive material that is antibacterial in purple leaf extract would increase so that the number of Streptococcus mutans extracts would decrease.

The results showed that purple leaf [Graptophyllum pictum (L.) Griff) is an antibacterial against Streptococcus mutans because it has secondary metabolite compounds 
such as polyphenols, tannins, alkaloids, flavonoids, alkaloids, and saponins.

Streptococcus mutans is a gram-positive bacteria. When the active mixture of an extract works on gram-positive bacteria, the compound binds to the peptidoglycan, damaging the cell wall. The growth of gram-positive bacteria can be inhibited.

Alkaloids work as an antibacterial by damaging the peptidoglycan component of bacterial cells so that the wall layer is not formed intact and causes bacterial cell death. Polyphenols work by reacting with bacterial cell membranes and causes bacterial cell lysis, denaturation of proteins, and inhibit the formation of cytoplasmic proteins, nucleic acids, and ATP-ase bonds in bacterial cell membranes. Tannin works by coagulating bacterial protoplasms, precipitating proteins, and binding to proteins to inhibit the formation of bacterial cell walls. Active flavonoids have antibacterial activity by causing denaturation of proteins found in cell walls that damage the composition and change the permeability mechanism of microsomes, lysosomes, and cell walls. ${ }^{15,16}$ Saponins can interact with bacterial cell walls, causing lysis because saponins can form a foam (which is like a detergent) that disrupt the surface tension of cell walls. ${ }^{15}$ The four active compounds work synergistically in inhibiting and eliminating Streptococcus mutans.

\section{CONCLUSION}

The purple leaf [Graptophyllum pictum (L.) Griff] was considered effective as an antibacterial against Streptococcus mutans. The MIC was at $3.125 \%$, and the MBC was at $6.25 \%$.

\section{Acknowledgment}

This study was conducted under the permission of the Microbiology Laboratory, Research Centre, Airlangga University, Surabaya, Indonesia.

\section{Statement of Authorship}

All authors participated in the data collection and analysis and approved the final version submitted.

\section{Author Disclosure}

All authors declared no conflicts of interest.

\section{Funding Source}

This paper was funded by the University of Airlangga.

\section{REFERENCES}

1. Indonesian Ministry of Health. Baseline Health Research Ministry of Health of Republic Indonesia. Jakarta; 2018.pp.93-96

2. Nedeljkovic I, De Munck J, Vanloy A, Nedeljkovic I, De Munck J, Vanloy A, et al. Secondary caries: prevalence, characteristics, and approach. Clin Oral Investig. 2020;24:683-91.

3. Ahmad S, Sinha S, Ojha S, Chadha H, Aggarwal B, Ajeet A, et al. Formulation and Evaluation of Antibacterial Herbal Mouthwash Against Oral Disorders. Indo glob j pharm. 2018;8(2):37-40.

4. Jiang Q, Kainulainen V, Stamatova I, Janket S-J, Meurman JH, Korpela R. Mouthwash Effects on LGG-Integrated Experimental Oral Biofilms. Dentistry Journal. 2020; 8(3):96.

5. Cieplik F, Jakubovics NS, Buchalla W, Maisch T, Hellwig E, AlAhmad A. Resistance Toward Chlorhexidine in Oral Bacteria - Is There Cause for Concern? Front Microbiol. 2019;10:587.

6. Liao Y, Brandt BW, Li J, Crielaard W, Van Loveren C, Deng DM. Fluoride resistance in Streptococcus mutans: a mini review. J Oral Microbiol. 2017 Jul 6;9(1):1344509.

7. Jiangseubchatveera $\mathrm{N}$, Liawruangrath $\mathrm{B}$, Liawruangrath $\mathrm{S}$, Teerawutgulrag A, Santiarworn D, Korth J, et al. The chemical constituents and the cytotoxicity, antioxidant and antibacterial activities of the essential oil of Graptophyllum pictum (L.) Griff. Journal of Essential Oil Bearing Plants. 2015;18(1):11-7.

8. Jiangseubchatveera $\mathrm{N}$, Liawruangrath $\mathrm{S}$, Teerawutgulrag $\mathrm{A}$, Santiarworn D, Pyne SG, Liawruangrath B. Phytochemical screening, phenolic and flavonoid contents, antioxidant and cytotoxic activities of Graptophyllum pictum (L.) Griff. Chiang Mai Journal of Science. 2017;44(1):193-202.

9. Indriana RA, Astuti P, Kurniawati A. Inhibition Test of Purple Leaf (Graptophillum pictum L.Griff) Methanol Extract toward Root Canal Bacteria's Growth. e-Journal Pustaka Kesehat. 2017;5(1): $145-50$.

10. Kusumaningsih T, Firdausi A, Diyatri I, Ridwan RD, Arundina I, others. Antioxidant Effects of Graptophyllum pictum Leaf Extract on Malondialdehyde (MDA) Levels of Mice Induced By a Toxic Dose of Paracetamol. J Krishna Inst Med Sci. 2018;7(3):59-64.

11. Rustini NL, Ariati NK. Identification of Active Antioxidant Compounds from Ungu Leaf Ethanol Extract (Graptophyllum pictum L. Griff). J Heal Sci Med. 2018;2(1):9-12.

12. Pratama MRF, Suratno S, Mulyani, E. Profile of Thin-Layer Chromatography and UV-Vis Spectrophotometry of Akar Kuning Stem Extract (Arcangelisia flava). Borneo Journal of Pharmacy. 2018; 1(2). $72-76$.

13. Bhutya RK. Colour Atlas of medicinal plants. Jaipur. Scientific Publisher; 2018. pp. 255.

14. Abubakar AR, Haque M. Preparation of Medicinal Plants: Basic Extraction and Fractionation Procedures for Experimental Purposes. J Pharm Bioallied Sci. 2020;12(1):1-10.

15. Anandhi D, Srinivasan PT, Praveen Kumar G, Jagatheesh S. Influence of flavonoids and glycosides from Caesalpinia coriaria (Jacq) wild as bactericidal compound. Int J Curr Microbiol App Sci. 2014;3(4): 1043-51.

16. Balinadoa LO, Chan M.A. Determination of Antimicrobial Properties of Crude Aqueous Leaves Extracts of Selected Medicinal Plants Using Resazurin-Based Microtiter Broth Dilution Method. Arabian Journal of Medicinal and Aromatic Plants. 2018; 4(2):1-14. 